University at Buffalo School of Law

Digital Commons @ University at Buffalo School of Law

Contributions to Books

Faculty Scholarship

2014

\title{
Animals and Law in the American City
}

Irus Braverman

University at Buffalo School of Law, irusb@buffalo.edu

Follow this and additional works at: https://digitalcommons.law.buffalo.edu/book_sections

Part of the Geography Commons, and the Law Commons

\section{Recommended Citation}

Irus Braverman, Animals and Law in the American City in Environmental Law and Contrasting Ideas of Nature: a Constructivist Approach 112 (Keith H. Hirokawa, ed., Cambridge University Press 2014)

This material has been published in Environmental Law and Contrasting Ideas of Nature: a Constructivist Approach edited by Keith $\mathrm{H}$. Hirokawa. This version is free to view and download for personal use only. Not for re-distribution, re-sale or use in derivative works. (c) Keith H. Hirokawa 2014.

\section{C. ${ }_{\text {COPYRIGHT }}^{\text {IN }}$}

This Book is brought to you for free and open access by the Faculty Scholarship at Digital Commons @ University at Buffalo School of Law. It has been accepted for inclusion in Contributions to Books by an authorized administrator of Digital Commons @ University at Buffalo School of Law. For more information, please contact lawscholar@buffalo.edu. 


\title{
Animals and Law in the American City
}

\author{
Irus Braverman
}

We must distinguish three kinds of animals. First, individuated animals, family pets, sentimental, Oedipal animals each with its own petty history, "my" cat, "my" dog. These animals invite us to regress, draw us into a narcissistic contemplation, and they are the only kind of animal psychoanalysis understands, the better to discover a daddy, a mommy, a little brother behind them ... And then there is a second kind: animals with characteristics or attributes, genus, classification, or State animals, animals as they are treated in the great divine myths.... Finally, there are more demonic animals, pack or affect animals that form a multiplicity, a becoming, a population, a tale. ${ }^{1}$

\section{INTRODUCTION}

Modern western cities are designed by humans and with humans in mind; indeed, nonhuman animals are conceived by many urban dwellers as being "out of place." However, a closer look at the contemporary city proves otherwise. Humans are not the majority of the city's members of Kingdom Animalia. In fact, bees, pigeons, rats, bats, rabbits, ants, wasps, dogs, cats, horses, chickens, bedbugs, and lice far outnumber humans. This nonhuman animal population constitutes what has been referred to in animal studies literature as a "shadow population" or a "subaltern animal town."3

Whereas a large and growing literature is dedicated to studying human populations in the city, not much has been written about nonhuman animals in this space. ${ }^{4}$ This chapter will explore the presence of nonhuman animals in the American city through a legal lens. In particular, it will address these

1 Gilles Deleuze and Felix Guattari, A Thousand Plateaus 240-241 (Brian Massumi trans., 1980).

$=$ Chris Philo \& Chris Wilbert, Animal Spaces, Beastly Places: New Geographies of Human Animal Relations (2000).

3 Jennifer Wolch, Kathleen West, \& Thomas E. Gaines, Transspecies Urban Theory, 13 ENv'T \& Planning D 735, 736 (1995).

4 Id. at 735 . 
largely overlooked questions: On the one hand, how are animals constructed by law and how does this construction translate into the animal's material existence in American cities? And on the other hand, how do humans and animals work in and around the classifications constituted by animal laws? I shall argue that alongside law's attempt to classify animals, a considerable administrative effort goes into keeping animals confined within their particular classifications.

I will begin this chapter with a few general contemplations about the legal classification of animals in American cities. I will then move to explore specific legal categories of animals, especially in their urban manifestation: domestic and companion animals, agriculture or livestock animals, wild ani mals, and pests. In each category, instances of reclassification will demonstrate the inherent messiness and fluidity of the legal ordering of animals as well as the legal struggles to redefine such ordering. Finally, the context of bee laws will provide ample ground to demonstrate how law's classificatory schemes and the human animal relations that ensue are performed in the American city.

\section{CLASSIFICATION IN ANIMAL LAWS}

The most prominent technology for regulating animals is their classification into a set of legal categories. Such legal categories largely defer to the Linnaean classification of Kingdom Animalia by phylum, class, order, genus, and species. ${ }^{5}$ Alongside this system, however, law classifies animals according to their relationship with humans. The vast majority of the animal kingdom fall into one or more of the following legal categories: wild, domestic, agriculture, pests, and laboratory animals, with each category representing a particular human animal relationship. Legal categories for animals are not always consistent, nor are they mutually exclusive. For example, a bee may be desirable for humans as a pollinator and honey maker but undesirable and thus unprotected when aggressive and stinging; and geese may be protected when defined as wild animals but may not be protected when defined as agricultural property to be raised and slaughtered, as game to be hunted, or as a nuisance to be culled.

The level of legal protections granted to animals within their particular categories and classifications also changes through time and place. For exam ple, the American peregrine falcon was protected in 1970 through its listing as an endangered wild species and was delisted from protection in 1999 after

5 See International Commission on Zoological Nomenclature, http://iczn.org/ (last visited Feb. 17, 2013). 
what was deemed the population's successful recovery. The particular ani mal human exchange permitted by various laws also varies. City by city and state by state, laws differ in terms of their prohibitions on keeping animals such as honeybees, potbellied pigs, and exotic animals in the city. These examples highlight the importance of categories and classifications for law's perform ances in the world. At the same time, they illuminate the challenges to law's categorical imperative, especially when the regulation of animals in the American city is at stake.

Animal classifications can be characterized according to the level of legal protection they grant from human inflicted harm. ${ }^{6}$ Every animal is either protected or unprotected, this classification translating into a prescribed set of legal actions humans may or may not perform with regard to humans, animals, and habitat. For protected wild animals, "No person shall, at any time of the year, pursue, take, wound or kill [them] in any manner, number or quantity, except as permitted by ... law." ${ }^{7}$ Nor can any person "buy, sell, offer or expose for sale, transport, or have in his possession any [animal] protected by law." ${ }^{8}$ By contrast, when classified as unprotected, animals are subject to an array of additional laws that determine human behavior in using, taking, or harming them (e.g., regulations over the extermination of pests). Animal geography scholars Jody Emel and Jennifer Wolch observe along these lines that invisible boundaries "historically divided the animal world into those worth protecting because they were seen as either part of nature (wildlife) or the human community (pets), and those not worth protecting because they were neither (farm animals) and constituted sources of profit and value."

In New York State, conservation laws govern myriad aspects of the animal human relationships. A quick read of the following legal text already reveals some of the major legal categories at work in this context:

5. a. "Unprotected wild birds" means the English sparrow and starling, and also includes pigeons and psittacine birds existing in a wild state, not domesticated. ${ }^{10}$

6 Mary Douglas, Purity and Danger; an Analysis of Concepts of Pollution and TABOO (1966).

7 Application of Fish and Wildlife Law, N.Y. Envtl. Conserv. Law \& 11-0107.

8 Id.

9 Jennifer R. Wolch \& Jody Emel, Animal Geographies: Place, Politics, and Identity in the Nature Culture Borderlands 14 (1998).

10 Bill number S1255 proposed an amendment to exclude the Monk Parakeet from "unprotected birds" in order to protect feral breeding populations escaped from the exotic pet industry. S1255-2011: Makes Monk (Quaker) Parakeets Protected Birds. 
b. "Protected birds" means all wild birds except those named in para graph a of this subdivision.

6. a. "Wildlife" means wild game and all other animal life existing in a wild state, except fish, shellfish and crustacea....

e. "Wild animal" shall not include "companion animal" as defined in section three hundred fifty of the Agriculture and Markets Law. Wild animal includes, and is limited to, any or all of the following orders and families: (1) Nonhuman primates and prosimians, (2) Felidae and all hybrids thereof, with the exception of the species Felis catus (domes ticated and feral cats, which shall mean domesticated cats that were formerly owned and that have been abandoned and that are no longer socialized, as well as offspring of such cats) and hybrids of Felis catus that are registered by the American Cat Fanciers Association or the International Cat Association provided that such cats be without any wild felid parentage for a minimum of five generations, (3) Canidae (with the exception of domesticated dogs and captive bred fennec foxes (vulpes zerda)), (4) Ursidae, (5) All reptiles that are venomous by nature, pursuant to department regulation, ...

7. "Protected insect" means any insect with respect to the taking of which restrictions are imposed by the Fish and Wildlife Law or regulations of the department pursuant thereto. ${ }^{11}$

This legal text illustrates a few interrelated points. First, it demonstrates the centrality of the terms "protected" and "unprotected." Second, it introduces a range of animal related classifications through which the animal world is perceived and then ordered: "wild," "companion," and "insect," as well as "hybrids" and "feral." Third, this text demonstrates law's heavy reliance on scientific distinctions, such as those between felines and canines (or "Felis catus" and "canidae") and, in particular, the contemporary importance of genetic pedigrees (e.g., in the cat's definition as going back for a minimum of five generations). ${ }^{12}$ Finally, this text also exemplifies law's desperate desire

11 Definitions, N.Y. Envtl. Conse Rv. Law $\$ 11-0103$ (McKinney 2011), available at http://codes. lp.findlaw.com/nycode/ENV/11/1/11-0103. See also Utah's definition of wildlife as: "(a) crustaceans, including brine shrimp and crayfish; (b) mollusks; and (c) vertebrate animals living in nature, except feral animals." UтAн Code ANN. \23-13-2 (West 2011).

12 This current reliance of law on genetic definitions seems to be a move away from Michel Foucault's reflections on animal classification as based on simple visible characteristics. In his words, "The plant and the animal are seen not so much in their organic unity as by the visible patterning of their organs. They are paws and hoofs, flowers and fruit, before being respiratory systems or internal liquids." Michel Foucault, The Order of Things 149 (1966). 
to organize things, alongside its anxiety about having an inherently limited capacity to successfully define what is shifting and unstable by definition: wildlife. In what follows, I will explore the central classifications of city animals in contemporary American law. I shall begin close to home.

\section{DOMESTIC ANIMALS, PETS, AND COMPANION SPECIES}

Historically, domestic animals were farm and working animals recognized as having "intrinsic value" under common law. ${ }^{13}$ In the past, many courts refused to expand the term "pets" to include cats, assuming that they had no intrinsic value. ${ }^{14}$ Nowadays, the Code of Federal Regulations (CFR) defines a pet as: "[A]ny animal that has commonly been kept as a pet in family households in the United States, such as dogs, cats, guinea pigs, rabbits, and hamsters. The term 'pet' excludes exotic animals and wild animals." ${ }^{15}$ In other words, a pet is circularly defined by the CFR as an animal that has traditionally been a pet. New York State regulations are clearer, but still quite broad, in their definition of a pet as "any domestic animal that has been adapted or tamed to live in intimate association with people but is not limited to dogs, cats, rodents, fish, birds, snakes, turtles, lizards, frogs and rabbits." ${ }^{\prime 6}$

Of all pets, only dogs must have a license in New York State. A human city resident is allowed to hold up to four dogs, for example, but an infinite number of cats. As principal objects of human care, dogs are also subject to regulations that include matters such as proper shelter, restraints, licensing and identifi cation, and medical treatments. ${ }^{17}$ Additionally, many states mandate rabies vaccinations with accompanying fees and certification. ${ }^{18}$ Requirements for the design of dog shelters serve as an example for the specificity of dog laws. According to an Oklahoma statute, for example, dog breeders must provide at least the following for an enclosure with one dog:

13 Animal Law, at 8.

14 See, e.g., Commonwealth v. Massini, 188 A.2d 816 (Pa. Super. Ct. 1963) (refusing to expand an animal cruelty statute beyond the precise wording of the statute: "equine animal, bovine animal, sheep, goat and pig"). See also Animal Law, id.

15 9 C.F.R. $\$ 1.1$.

16 N.Y. Gen. Bus. Law \& 750-a (McKinney 2011).

17 See, e.g., Buffalo, N.Y. Code ch.78, art. III (1999) (providing detailed instructions about a "public pound", seizure, redemption periods and impoundment fees, adoption processes and fees, and further licensing requirements). See also Irus Braverman, Legal Tails: Policing American Cities through Animals, in Urban Policing, Securitization, and Regulation (Randy K. Lippert \& Kevin Walby eds., Routledge 2013), pp. 130-144.

18 See, e.g., S.C. Code Ann. \$ 47-5-60 (2011). 
The mathematical square of the sum of the length of the dog in inches (measured from the tip of its nose to the base of its tail) plus 6 inches; divided the product by 144, times 2. Mathematically, the space the commercial pet breeder must provide for the first dog equals $2 \times[($ length of $\operatorname{dog}$ in inches +6$) \times$ (length of dog in inches +6$) / 144] .^{19}$

Dog "disposal" is also heavily regulated, as federal norms define proper ways to transport and sell dogs. ${ }^{20}$

In addition to dogs and cats, birds, reptiles, amphibians, and other animals may be considered pets or, in the current fashion, "companion species." For example, a New York court recently held that a goldfish was a companion animal under an anticruelty statute. In that case, a boy who owned a goldfish regularly attended to it and even named it after himself. ${ }^{21}$ The animal was thereby classified by the Court based on the human animal relationship established in the particular case rather than by the independent identity of the animals. Courts have also considered other circumstances, such as the duration of the animal's captivity, its training, and its behavior, to find that a monkey was a domesticated pet, in the case of Rolling Meadows v. Kyle, ${ }^{22}$ but that a pet monkey was a wild animal under a rabies control statute because monkeys are not a "common domestic species," in the case of Keeble v. Cisneros. $^{23}$

Although pets are not confined to city spaces, because they have flourished in urban settings they are often seen as a quintessentially urban phenomenon. The pets' ownership and control by humans in the highly policed space of the city, as well as their significant emotional role in the family, may serve to explain why they are often subject to heightened regulation. ${ }^{24}$ For the most

19 Okla. Admin. Code $\int 532: 15-3-3$ (2011).

207 U.S.C.A. $\$ 2131$ (West 2011). The cremation of a dog in New York is considered a transaction and regulated by the General Business Law. See N.Y. Gen. Bus. LAw art. 35-C (McKinney 2011).

${ }^{21}$ People v. Garcia, 812 N.Y.S.2d 66 (N.Y. App. Div. 2006). In this case, the Court considered the scope of New York law for aggravated cruelty and its application to a pet goldfish. The dispute turned on whether the goldfish was a "companion animal" under the statute to constitute a felony. The defendant had stomped to death the pet goldfish of a nine-year-old boy, and the Court found that child's pet goldfish fell within the meaning of "companion animal" under the statute, and thus the defendant was convicted of aggravated cruelty to animals in violation of the Agriculture and Markets Law \$353a(1).

22 City of Rolling Meadows v. Kyle, 494 N.E.2d 766 (Ill. App. Ct. 1986).

23 Keeble v. Cisneros, 664 F.Supp. 1076 (Tex. 1987).

24 See, e.g., Andrea Hart Herbster, More than Pigs in a Parlor: An Exploration of the Relationship Between the Law and Keeping Pigs as Pets, 86 Iowa L. Rev. 339 (2000); Rebecca J. Huss, Separation, Custody, and Estate Planning Issues Relating to Companion Animals, 74 U. Colo. L. REV. 181 (2003). 
part, companion animals are policed through their human caregivers, or "spokespersons." 25

The distinctions between "wild" and "domesticated" animals thus enable and legitimize particular forms of human policing. Such forms of policing can vary not only with regard to distinct species but also between two individuals from the same species, as in the two cases involving pet monkeys mentioned earlier. The fluidity of these categories entails that their regulation becomes ever more complex.

Yet even at its very heart, the category of "pet" is not static. Pets may "jump" categories based on their actions and the actions of their human caregivers. For example, escaped pets are reclassified as "feral" or "stray" a particular category of wild animals with a unique set of legal norms. ${ }^{26}$ Similarly, wild animals may become pets through their training, as in the example of the tamed monkey of Rolling Meadows v. Kyle. By acting as domestic and tame or by escaping into the wild, pets effectively mobilize their legal classification as companion animals to reclassify as feral or wild, and vice versa from wild they become companion animals. Such physical trajectories that are performed by animals, and the legal trajectories that ensue intersect, parallel, and sometimes contradict human trajectories as humans capture, train, acci dentally release, save, or kill an animal. These interactive human animal trajectories and their regulation determine the relevant classifications that apply in each case, their dynamics, and their policing powers.

Another classificatory scheme that facilitates the policing of nonhuman (and human) animals in the American city is the distinction between pets and livestock. For example, certain humans have taken to keeping Vietnamese potbellied pigs as pets in their homes, a contested behavior in municipalities

25 The term "spokesperson" was coined by Actor Network Theorists to highlight how humans have come to speak for nonhumans. See, e.g., Michel Callon, Some Elements of a Sociology of Translation: Domestication of the Scallops and the Fishermen of St. Brieuc Bay, in Power, ACTION, AND BELIEF: A NEW SOCIOlOgY OF KNOWledge? (John Law ed., 1986). For a detailed exploration of how humans in American cities are policed through animals, see Irus Braverman, Legal Tails: Policing American Cities through Animals, Urban Policing, Securitization, and Regulation (Randy K. Lippert \& Kevin Walby eds., Routledge 2013), pp. 130-144.

26 Alan M. Beck, The Ecology of Stray Dogs: A Study of Free Ranging Urban Animals (1973); see also N.Y. Agric. \& MkTs. Law, ch. 69, art. 5 \& 74 (McKinney 2011) (defining "feral" as an undomesticated or wild animal). Feral animals may include untamed buffalo, dogs, horses, and the like that face starvation, infection, and attacks from other animals. Feral animals also face eradication by humans through various techniques. The ASPCA defines "stray" as an animal that has become lost or abandoned but is tame and comfortable around people. As such, stray animals are more dependent on humans for survival than feral animals and are typically unable to cope with life in the wild. See The American Society for the Prevention of Cruelty TO ANimals (ASPCA), http://www.aspca.org (last visited Feb. 17, 2013). 
with zoning or public health codes against keeping livestock. ${ }^{27}$ The issue has been resolved with different outcomes in different municipal jurisdictions. In some cities, livestock is defined by its purpose for farming, therefore allowing the keeping of pigs as pets. Other municipalities outlaw hogpens rather than pigs, therefore allowing pigs in the house because it is clearly not a hogpen. Finally, where pigs and pigsties are explicitly forbidden as nuisances in health codes, no exception for pet pigs is permitted: in these municipalities a pig is a pig always a forbidden nuisance. This example reiterates the commitments humans make in their classification scheme and the impact that these classi fications have on the mutual life of humans and animals in the American city.

\section{AGRICULTURAL ANIMALS OR LIVESTOCK}

Whereas the boundaries between pet and livestock can often be blurry, American laws take great pains to define and protect these classificatory schemes so as to make them seem inevitable and even natural. For example, Title 7 of the United States Code Annotated defines livestock as:

cattle, elk, reindeer, bison, horses, deer, sheep, goats, swine, poultry (including egg producing poultry), fish used for food, and other animals designated by the Secretary (at the Secretary's sole discretion) that

(A) are part of a foundation herd (including producing dairy cattle) or offspring; or

(B) are purchased as part of a normal operation and not to obtain additional benefits under this subchapter. ${ }^{28}$

In Giles v. State, ${ }^{29}$ a New York court held that livestock are domesticated animals that have become naturally harmless and docile through many years of close contact with people. More generally, courts have distinguished this state of agricultural domestication from a domestic pet whose principle role is companionship. ${ }^{30}$ The domestic/domesticated distinction has been justified as necessary for regulating livestock's key role in farming and for ensuring human health, public safety, and food security..$^{31}$

27 This paragraph is drawn from Andrea Hart Herbster, More than Pigs in a Parlor: An Exploration of the Relationship Between the Law and Keeping Pigs as Pets, 86 Iowa L. Rev. 339 (2000).

287 U.S.C.A. $\$ 1471$ (West 2011).

29431 N.Y.S.2d 781 (N.Y. Ct. Cl. 1980).

30 Supra note 18 .

${ }^{31}$ However, some regulations are less clearly connected to health than others. For example, one statute concerning bridge tolls states that, "Any toll gatherer ... may stop any person with automobiles, wagons, carts, or other vehicles ..., and all horses, cows, cattle or other animal or animals, from entering... until the toll herein provided for shall have been paid." N.J. SтAт. ANN. \$27:19-29 (West 2011). 
Nonetheless, the distinction between domestic and domesticated did not always exist as such. Preindustrial city dwellers used to put up with the noise, odors, pestilence, and disease associated with livestock inside their homes. ${ }^{32}$ With the technological advances and changes in urban design over the last 150 years, horses have largely been replaced with trains and auto mobiles, and slaughtering and preserving meat mostly occurs now outside of the city, before it is brought into the urban market. Urban planners have actively propelled this exodus of animals from the city. Land use regulations and zoning policies have segregated agriculture from residential, commer cial, and industrial activities. At the same time, animal control ordinances have been established to regulate the care and keeping of livestock. Generally prohibitive of many livestock activities, these new ordinances have effectively banned all animal farming in towns. ${ }^{33}$ In the last decade, the local foods movement has gained traction and urban agriculture is on the rise. As a result, livestock is finding its way back into the city. Cities are also increasingly heterogeneous and culturally diverse, thereby introducing behaviors that sometimes conflict with American cities' municipal codes on livestock keeping and slaughtering. Regulations on permits and licenses commonly situated in public health chapters or as a section of the animal control chapter of municipal codes play a particularly important role in prescribing how animals are to be treated, outlining specifications of enclo sures and confinements, identifying agency or organizational oversight for inspections, and listing other procedural and technical conditions that must be met before livestock keeping is allowed. ${ }^{34}$ These regulations have facilitated changes in what are considered to be legally acceptable behaviors.

In a comprehensive study of communities residing in twenty two cities across the United States, legal scholar William Butler found that although most livestock keeping activities are limited to agricultural zones outside cities, cities are increasingly allowing the keeping of chickens or bees even within residential districts. Such an inclusion of bees and chickens in urban space, Butler explains, is likely due to the fact that they have been the most amenable animals in residential areas with fewest associated nuisances ${ }^{35}$ Butler categorizes various localities based on their level

32 William H. Butler, Welcoming Animals Back to the City: Navigating Public Health Tensions of Urban Livestock to Achieve Healthy and Resilient Communities, in Working Paper Series, FLA. ST. Univ. 3 (2011).

33 Id at 4. See also Carolyn Steel, Hungry City: How Food Shapes Our Lives (2009).

34 See supra note 35.

35 Butler, supra note 32 , at 16. 
of restrictions on chicken populations via lot size, setbacks, and number limitations:

Although some municipalities do not establish a maximum allowable num ber of animals, some do limit the total number of animals allowed by each property owner in the city. Ann Arbor only allows 4 chickens and 2 hives of bees per property owner. Baltimore, MD allows no more than 4 chickens and 125 pigeons. The Kansas City, MO ordinance limits adult chickens and other domestic fowl to 15 , adult rabbits to 10 , and larger livestock animals to 2 . Missoula, MT and South Portland, ME allow 6 chickens while Madison, WI and Rogers, AK allow $4 \cdot{ }^{36}$

Although chickens are increasingly allowed back into many American cities, few cities have allowed roosters back in without significant restrictions. Butler indicates, for example, that "in even some of the most permissible localities on other issues, like King County, Washington, roosters are prohibited outright." In other cases, roosters are allowed with caveats. Cleveland allows roosters but the code specifies that it is unlawful "to keep or allow to be kept any animal or bird that makes noise so as to habitually disturb the peace and quiet of any person in the vicinity of the premises." 37 Similarly, Stamford, Connecticut, allows roosters but specifies that,

No person shall keep any rooster in such location that the crowing thereof shall be annoying to any person occupying premises in the vicinity. Upon complaint of any such person so annoyed, the Director of Health shall have authority to order the owner of such rooster to remove the same so that such annoyance shall cease. ${ }^{38}$

Butler concludes this discussion by anticipating that "mute roosters may soon become popular in cities," indicating, perhaps, the development of a legal sensibility on the part of urban dwellers that might embrace biotechnological artificiality in order to maintain its adherence to the letter of the law. ${ }^{39}$

Evidently, farm animals are subclassified and regulated according to their use for humans (e.g., producing eggs) and their level of interference with civilized urban life (e.g., crowing at inconvenient hours). They are then prescribed a certain degree of legal protection, which differs both in text and in institutional apparatus from the legal protections assigned to pets, pests, and wild animals.

${ }^{36}$ Id. at 23.

37 Cleveland, Ohio, Code ch. 347, \$347.02(g) (2010).

${ }^{3}$ Id. at 25 .

39 Id. 


\section{WILD ANIMALS}

Whereas domestic animals are often perceived as quintessentially urban, wild animals are seen as existing outside the city and thus as unaffected by its laws. At the same time, the legal and physical barriers that prevent humans from shifting their residency easily from one jurisdiction to another do not apply to wild animals. Wild birds often migrate in and out of the city and wild insects live in between these spaces. This section will demonstrate how animals travel the urban wild divide and how law in turn regulates this mobility. ${ }^{\circ}$

As mentioned, New York State law defines wildlife as "all animal life existing in a wild state." ${ }^{11}$ The federal definition of "wildlife" in conservation law refers to any "wild member of the animal kingdom whether alive or dead, and regardless of whether the member was bred, hatched, or born in captivity, including a part, product, egg, or offspring of the member." ${ }^{2}$ A federal code on endangered species defines, additionally, that endangered "fish or wildlife" can be "any member of the animal kingdom, including without limitation any mammal, fish, bird (including any migratory, nonmigratory, or endangered bird for which protection is also afforded by treaty or other international agreement), amphibian, reptile, mollusk, crustacean, arthropod or other invertebrate, and includes any part, product, egg, or offspring thereof, or the dead body or parts thereof." 43

The classification of an animal as wild carries with it a set of physical and legal implications. A wild animal may receive more protections than a farm animal, especially if it is also classified as endangered or threatened. Yet wild animals commonly do not receive the same degree of protection as compan ion animals under criminal anticruelty acts, even when they enter urban spaces and homes. ${ }^{44}$

Many states and cities limit an individual's ability to own a wild or exotic animal. New York State code states, for example, that, "The State of New York owns all fish, game, wildlife, shellfish, crustacea and protected insects in the state, except those legally acquired and held in private ownership. Any person who kills, takes or possesses such fish, game, wildlife, shellfish, crustacea or protected insects thereby consents that title thereto shall remain in the state for

$4^{\circ}$ For a detailed discussion of animal mobility in the American city, see Irus Braverman, Animal Mobilegalities: The Regulation of Animal Movement in the American City. Humanimalia 5(1): 104-135 (2013).

41 N.Y. Envtl. Conserv., ch. 43-B, art. 11 (1996).

4216 U.S.C.A. \$ 668ee (West 2011).

4316 U.S.C.A. $\$ 1532$ (West 2011).

44 Pamela Frasch, Kathy Hessler, Sarah Kutil, \& Sonia Waisman, Animal Law in a Nutsheli 10-11 (2011). 
the purpose of regulating and disposition." ${ }^{45}$ In other words, even when wild animals are on private property, they are generally defined as state property. ${ }^{6}$ Wild animals are also subject to report requirements. For example, New York General Municipal Laws state that: "with the exception of pet dealers, every person owning, possessing, or harboring a wild animal or a dangerous dog within this state shall report the presence thereof to the clerk of the city, town, or village in which such wild animal or dangerous dog is owned, possessed, or harbored." 47

Although legal norms define certain animals as wild, the test for determin ing their wildness remains unclear. American courts have inconsistently applied different traits when considering the classification of nonhuman animals as wild. For example, in State v. Mierz, ${ }^{48}$ the Washington Supreme Court ruled that the statutory term "feral domestic mammals" refers to cats and dogs that have escaped their owners, as opposed to wild animals such as coyotes. Although to a casual observer a tamed coyote and a feral dog may seem undistinguishable, the coyote's wild origins and the dog's domestic origins were found to be crucial for triggering different legal classifications, which then invoked a range of practical consequences. For example, the Court held that although the feral dog may be kept as a pet, the possession of the tame coyote was prohibited. ${ }^{49}$ New York courts approached the same classifications differently. In a case from the 180os, a New York court deter mined that specific geese were tame and not wild because they were gentle, would eat from one's hand, and had lost the disposition to fly away..$^{\circ}$ In a more recent case that concerned a squirrel kept in captivity without a license, an Ohio court found that the squirrel had already exceeded the natural life expectancy of squirrels in the wild and was therefore no longer wild..$^{51}$ Various courts have thus defined the term "wild" differently, triggering differ ent courses of events (such as the prohibition from keeping certain animals in a domesticated state or from releasing them into the wild) despite the similarities between the animals involved. Another classification that

45 State Ownership and Control, N.Y. Envtl. Conserv. Law \& 11-0105.

$4^{6}$ Wild animals that inhabit American zoos are an exception to the res commons ownership category, as they are typically owned by the individual zoos. See Irus Braverman, Zooland: The Institution of Captivity 137-139 (2012).

47 N.Y. Gen. Mun. Law \& 209-cc (McKinney 2011).

$4^{8}$ State v. Mierz, 901 P.2d 286 (Wash. 1995). For a fuller discussion, see Frasch et al., Animal Law in a Nutshell 10-11 (2011).

49 But see abovementioned discussion on City of Rolling Meadows v. Kyle, 494 N.E.2d 766 (Ill. App. Ct. 1986).

5o Amory v. Flyn, 10 Johns. 102 (N.Y. Sup. Ct. 1813) as quoted in id. at 11.

${ }_{51}$ Division of Wildlife v. Clifton, 692 N.E.2d 253 (Ohio 1997), as quoted in id. 12. 
frequently overlaps that of wild animals and that is afforded heightened significance in the city is that of "pests."

\section{PESTS}

American Federal law defines the term "pest" as:

(1) any insect, rodent, nematode, fungus, weed, or (2) any other form of terrestrial or aquatic plant or animal life or virus, bacteria, or other micro organism (except viruses, bacteria, or other micro organisms on or in living man or other living animals) which the Administrator [of the Environmental Protection Agency] declares to be a pest. ${ }^{52}$

Similar to the definition of "pet," a pest is defined as any organism that is declared by the law as such. State laws generally follow the wording of the federal model, ${ }^{53}$ although certain governmental agencies utilize a narrower definition of the term. According to New York's Agriculture and Markets Law, for example, a pest is "any invertebrate animal, pathogen, parasitic plant or similar or allied organism which can cause disease or damage in any crops, trees, shrubs, grasses or other plants of substantial value." ${ }^{54}$ A Florida statute designates pests as "an arthropod, wood destroying organism, rodent, or other obnoxious or undesirable living plant or animal organism," 55 whereas an Arkansas ordinance grants cities and towns the authority to "prevent injury or annoyance within the limits of the municipal corporation from anything dangerous, offensive, or unhealthy and cause any nuisance to be abated." ${ }^{56}$

A pest is thus "a term that is nicely ambiguous in being simultaneously technical and moral." ${ }^{\prime \prime}$ As illustrated in the language of the abovementioned laws, the pest classification is founded on the human relationship to the animal at stake as a nuisance, an annoyance, or as being altogether obnoxious. Many of the everyday interactions between humans and animals that would render the latter obnoxious occur in the space of the city. The definition of pests is, in other words, highly relational; it is also very much culture, time, and site specific. For example, whereas pigeons were once treasured for their cultural

$5^{2} 7$ U.S.C.A. $\$ 136$ (West 2011) (emphasis added).

53 E.g., N.Y. Envtl. Conserv. LaW \$33-0101 (McKinney 2011).

54 N.Y. Agric. \& Mkts. Law $\mathbb{1} 149$ (McKinney 2011) (emphasis added).

55 Fla. Stat. Ann. $\$ 482.021$ (West 2011) (emphasis added).

$5^{6}$ Ark. Code Ann. \& 14-54-103 (West 2011) (emphasis added).

57 Gary Alan Fine \& Lazaros Christoforides, Dirty Birds, Filthy Immigrants, and the English Sparrow War: Metaphorical Linkage in Constructing Social Problems, 14.4 Symbolic INTERACTION 375, 375 (1991). 
value, they are increasingly regulated as "rats with wings." ${ }^{8}$ Once a protected wild species in New York State,

$[\mathrm{T}]$ he local legislative body of any city, town or village ... may issue a permit to any person to take pigeons at any time and in any humane manner in such municipality, whenever [the legislature] finds that pigeons within such municipality are or may become a menace to public health or a public nuisance ... 59

The legal definition of an animal as a pest engenders a set of consequences in the material world, and especially in the city. Of the various animal categories, pests are probably afforded the weakest legal protections. They are "outlaws" in the Agambenian sense: their bodies are banned and they may be killed by anybody, ${ }^{6 \circ}$ or at least by licensed parties. A company for pest removal situated in the City of Buffalo, New York, and entitled "Good Riddance," assures the public on its website that it will leave behind, "a safe, clean environment free of odor and harmful bacteria," promising that "whatever type of pest is bothering you, ... Good Riddance can deal with it, removing your problem immediately." ${ }^{\prime 1}$ The promotional materials of such companies depict an environment with animal pests as hazardous, dirty, and harmful, packaging such pests as a problem to be removed. Pest control and "removal" is thus perceived as restoring the clean, sanitary, and safe urban environment.

Among the various subcategories of pests, the most outlawed are probably those that humans have purposefully or inadvertently transported to a new environment outside their natural range, also defined as "nonnative" or "alien" species. When an alien species is classified as a pest that "does or is likely to cause economic or environmental harm or harm to human health" ${ }^{n 2}$ it is further subcategorized as an "invasive" species. Under the Lacey Act, if the species is particularly harmful or injurious to "human beings; the interests of agriculture, horticulture, forestry, or wildlife; or wildlife resources," it is banned from

$5^{8}$ Colin Jerolmack, How Pigeons Became Rats: The Cultural-Spatial Logic of Problem Animals, 55 Social Problems (2008). Jerolmack describes how pigeons were a bird admired and hunted in New York in the early 1900s. In the 1940s and 1950s, pigeons were increasingly seen as a nuisance and potential health threat, leading to bans on feeding pigeons and instances of poisoning or shooting them. In the 196os, two deaths were rhetorically linked to pigeons, resulting in their renaming as "rats with wings" and in the public's call for their extermination in the city.

59 Pigeons, N.Y. Envtl. Conserv. Law $\mathbb{1 1} 11-0513$.

6o Georgio Agamben, Homo Sacer. Sovereign Power and Bare Life (1998).

61 Good Riddance, Inc., available at http://www.goodriddanceinc.com/Pest-Control-BeesWasps-Hornets.aspx (last visited Oct. 7, 2011). The manager of this company refused to speak with me.

${ }^{62}$ Executive Order 13112, establishing the National Invasive Species Council, available at http:// www.invasivespeciesinfo.gov/laws/execorder.shtml. 
importation and violations can be punished by up to six months in prison and a $\$ 5,000$ fine. $^{63}$

Unlike the designations of wild and domesticated, pests (and invasive pests in particular) occupy specific moral valences. These serve to distinguish the types of interactions between humans and animals that are typically termed "nuisances" or "dangers" from interactions with certain acceptable animals, such as cats, dogs, or even wild coyotes. Pests and invasive species present a moral danger, not just a physical one: an unacceptable incursion into the human world that threatens the urban way of life. By regulating these incur sions in such a way that these animals are deemed "killable," the law effec tively places these animals outside of the law, in the Agambenian sense, allowing, indeed prescribing, their extermination.

\section{BEE LAWS: TO BEE OR NOT TO BEE?}

Bees are an excellent example of the fluidity of legal classifications and their translation into particular human animal relations in the American city. Bees are uniquely mobile. They also pollinate 80 percent of the world's plants, including 90 different food crops. This means that one out of every three or four human bites of food is courtesy of a honeybee. ${ }^{64}$ Indeed, "[i]f the bee disappeared off the surface of the globe, then man would have only four years of life left. No more bees, no more pollination, no more plants, no more animals, no more man." ${ }^{65}$ At the same time, humans also fear bees, and especially the African Killer Bee. They also fear for their agriculture, as the recent Colony Collapse Disorder has taken an increasing toll on this population. ${ }^{66}$ Humans thus both fear the bee and depend on it for survival. This ambivalence translating

63 U.S. Fish and Wildlife Service Injurious Wildlife Factsheet, available at http://www.fws.gov/ fisheries/ans/pdf files/InjuriousWildlifeFactSheet2007.pdf (summarizing the Lacey Act, 18 U.S.C. 42; 50 CFR 16). Florida has the largest problem of invasive reptiles and amphibians in the world. The introduction of new species - claimed to be largely a result of pet stores that sell exotic animals - includes snails and snakes that pose a danger to the health and safety of plants, animals, and humans. In reaction to this growing concern, Florida's legislature enacted laws prohibiting the introduction of nonnative reptiles and amphibians, and in fact banned individuals from owning large reptiles. Bill Kaczor, Florida Has the Worst Invasive Reptile, Amphibian Problem, The Gainesville Sun, Sep. 15, 2011. Also located at 9/15/11 AP Alert FL 21:35:51).

${ }^{6}$ USDA: Honey Bee Research, available at http://www.ars.usda.gov/Research/docs.htm? docid 11059 (last visited Oct. 18, 2013).

${ }^{6}$ See Jimmy Lee Shreeve, Bee Decline Threatens Our Dinner and the Countryside, The Telegraph, Aug. 3, 2007 (quoting Albert Einstein).

66 Alexei Barrionuevo, Honeybees Vanish, Leaving Keepers in Peril, New York Times, February 27, 2007, http://www.nytimes.com/2007/02/27/business/27bees.html (last viewed Oct. 21, 2011). 
into a complex set of legal norms and practices, some of which I will briefly illustrate.

Like chickens, bees were historically excluded from many American cities but are currently making their way back. ${ }^{67}$ The City of Buffalo, New York, is an example of such current changes in public opinion that have called for the bees' reintroduction into the space of this city. Buffalo's City Charter Ordinance does not address bees or beekeeping; it addresses only cattle and pigeons. ${ }^{68}$ Nonetheless, Buffalo's municipal officials claim that urban bee keeping is illegal because bees fall under the section of the ordinance that addresses property maintenance. This section states: "[g]rounds, buildings and structures shall be maintained free of insects, vermin and rodent harborage and infestation." ${ }^{69}$

Recently, local food initiatives and interested residents in Buffalo have been fighting against the municipal interpretation of the charter and pushing toward the legalization of bees in the city. One of the residents was quoted saying that "[h]oneybees exist here already; they swarm here. I catch my swarms in the city." Others have emphasized that "[b]ees are a critical step in urban food production." ${ }^{\circ}$ Philip Barr is a Buffalo resident. He cultivated bees until the winter of 2010, when he had to cease his practice because of the City's criminalization of beekeeping through its new interpretation of the charter. Now Barr is working to promote the legalization of bees in the city, arguing that beekeeping in the city is an important act of global conservation. In his words,

Bees are at great risk and everybody could do something about the problem. This is unlike dolphins, whales, or the white tiger of China, where few people have resources and access to help solve the problem. When it comes to bees, we cannot survive without bees, our economy depends on bees. So, everybody

67 The American Beekeeping Federation, Inc., is the beekeeping industry's national organization. Alongside this organization, a range of local beekeeping organizations has emerged - e.g., the Back Yard Beekeepers Association and Backwards Beekeepers. See Backyard BeEkeEPers Association: A Club for the Hobbyist Beekeeper, based in Southwestern Connecticut, www.backyardbeekeepers.com (last visited Oct. 10, 2011) (providing information to the general public about honey bees and the how-tos of beekeeping, as well as the benefits of bees and beekeeping in various communities); see also BACKWARDS BEEKEEPERS: BACKWARdS is THE NEW ForWARdS!, www.backwardsbeekeepers.com (last visited Oct. 10, 2011) (a California-based organization promoting the reliance on "observation and natural practices" to keep bees thriving, instead of the use of pesticides, chemicals, or other treatments to control bee populations).

68 Buffalo, N.Y., Code ch.341, art. II \$341-348 (2001).

$69 \mathrm{Id}$.

$7^{\circ}$ Anne Neville, Has the Time Arrived for Beehives in the City? The Buffalo News, Sept. 1, 2011. 
can have a beehive ... If you outlaw bees in the city, you cut off a large possibility for improvement. $^{71}$

Atlanta, Georgia, has gone much farther than Buffalo in legalizing bees in the city by actively promoting legal beekeeping. This approach has triggered a myriad of legal stipulations. Under the Georgia Code, bees are classified as agricultural products. ${ }^{72}$ The code also prescribes licenses for the sale of bees, prohibitions against any restrictions of honeybee production, and regulation regarding the importation of honeybees. ${ }^{73}$ The code establishes, along these lines, that "no county, municipal corporation, consolidated government, or other political subdivision of this state shall adopt or continue in effect any ordinance, rule, regulation, or resolution prohibiting, impeding, or restrict ing the establishment or maintenance of honeybees in hives." ${ }^{4}$ Georgia law also establishes that "inspections will be made by the agricultural commis sioner to ensure the combating and spread of bee diseases, Africanized bees, or any other threat to honeybees throughout the state." Finally, Georgia law states "that any bees or fixtures are infected with any contagious or infectious disease or that such bees or fixtures have been exposed to danger of infection by such diseases, that any honeybees have become Africanized, or that honeybees are confronted with any other threat in this state, the Commissioner may require the destruction, treatment, or disinfection of any such infected or exposed bees, hives, fixtures, or appliances." 75 In other words, beehives in Georgia are subject to inspection and any hive exhibiting signs of aggressive Africanized bees or infection with Colony Collapse Disorder is targeted for extinction.

Historically, Africanized honeybees, colloquially termed "killer bees," are a strain of bees that were bred in Brazil in the 1950 os as a cross between African

${ }^{71}$ Telephone Interview with Philip Barr, in Buffalo, N.Y. (Oct. 2, 2011).

72 Ga. Code Ann. \& 2-7-92 (13), \& 2-10-81 (West 2011).

73 Ga. Code Ann. \$2-14-40-47 (West 1982).

${ }^{74}$ In Georgia, inspection is done by the Commissioner of Agriculture. Anyone wishing to sell bees must acquire a license and pay a fee of $\$ 25.00$. GA. Code AnN. $\int 2-14-40$ (West 2011). For example, section 2-14-43 of the Code provides for the inspection of honeybee colonies:

The Commissioner may require the registration and inspection of honeybee colonies as needed. Such inspections shall be made for the primary purpose of combating the spread of bee diseases, Africanized bees, or any other threat to the honeybees in the state. All persons subject to this article shall be provided reasonable opportunity to assist the inspectors in the inspection of such colonies.

Honeybees are further addressed in Georgia Law under the title "Property", which provides that honey deposited by bees in a tree shall belong to the owner of the tree even if the bees were hived by another person. Ga. Code AnN. $\int 44^{-1-9}$ (West 2011).

75 Ga. Code Ann. \& 2-14-43, \21-14-44 (West 2011). 
and European honeybees. They were hybridized to increase honey production in tropical conditions. As a result of their accidental release into the wild, ${ }^{76}$ Africanized honeybees spread as far north as Texas, causing much panic along the way. They have come by their "killer" moniker because they will "viciously attack people or animals that unintentionally stray into their territory." 77

The USDA recently defined killer bees as an "invasive species," $7^{8}$ a definition that has in turn triggered a set of effects on their legal and material state in American cities. Whereas the European bee is defined as naturalized, ${ }^{79}$ gentle, civilized, and even essential to humans, the Africanized bee is defined as invasive, dangerous, and even deadly. ${ }^{80}$ Consequently, while European honeybees are afforded myriad legal pro tections, Africanized bees not only lack such protection but are also targeted for extermination. ${ }^{81}$ In between these extreme states, wild bees that do not

${ }^{6}$ See The Free Dictionary, http://www.thefreedictionary.com/Africanized+honey+bee (last visited Oct. 7, 2011).

77 See Killer Bee Africanized Honey Bees Bee Attacks in Arizona, http://phoenix. about.com/cs/desert/a/killerbeeso1.htm (last visited Oct. 18, 2013).

$7^{8}$ See USDA: NATIONAL Invasive Species INFORMaTiOn CENTER: Africanized Honeybee (APIS MELlifERA SCUTELlata), http://www.invasivespeciesinfo.gov/animals/afrhonbee.shtml (last visited Oct. 18, 2013).

79 The term "naturalized" is used here in the ecological sense as an exotic species that is introduced in a new environment and sustains itself by reproduction but also recalls the "naturalization" of foreign residents when they gain citizenship in their new country.

8० Although it is also geographically descriptive, the use of the term "Africanized" to name this bee is also highly racial and an instance in which animals serve as displacements of human fears. The bee is defined as aggressive and uncivilized, in relation to the civilized and gentle European honeybees. Fears of dark Africa and death are projected onto this animal, which has probably not caused more deaths than its "gentler" European counterpart. See Bayard Webster, "Killer Bees" Approaching U.S. Revive Crop Fears, N.Y. Times, Jul. 13, 1982 (describing some of the origins of the Africanized bee fears). Gary Alan Fine and Lazaros Christoforides study another instance in which animals serve as displacements of human fears. Their study focuses on the "Great English Sparrow War," a moniker that refers to the diffusion of English sparrows into North America in the second half of the nineteenth century and the role of metaphor in the construction of social problems. The authors suggest that "The nativism evident in the reaction to immigrant laborers was equally evident in a biological nativism which turned its hostility to these birds who found American soil so much to their liking." See Gary Alan Fine and Lazaros Christoforides, Dirty Birds, Filthy Immigrants, and the English Sparrow War: Metaphorical Linkage in Constructing Social Problems, 14 Symbolic Interaction 375, 377 (1991). The following clarification is also relevant in the Africanized bees context: "Our claim is not that the proponents of attacks on sparrows cynically manipulated nativist rhetoric in order to inflame passions, but rather this set of nativist beliefs made sense in explaining the dangers of a foreign interloper to the community of American birds." Id.

${ }^{81}$ And yet, European honeybees are not native to North America. In the words of beekeeper Philip Barr, "honeybees are not native to this country. So, since the time that they were brought by the Europeans, they have been selectively bred and managed. However, the more feral the hive evolves, the more that the domesticated traits fade." See supra note 95. 
serve humans for the mass production of honey are not afforded legal protection under many statutes. ${ }^{82}$

Honeybees have been categorized under nearly every animal classification. Any given hive may be defined as either domestic or wild, depending on whether it is managed by a beekeeper. It may also "jump" between categories by absconding or swarming away from its hive or by caught from the wild by a beekeeper. Whereas some honeybees are part of the Lacey Act's list of inju rious invasive species, others function like domestic farm animals. The mobility of honeybees has resulted in the mobilization of various legal classifications in order to protect humans from this insect; at the same time, because humans also depend on the bee, legal classifications have also been established to protect bees from humans.

\section{CONCLUSION}

This chapter has skimmed through a variety of animal laws and regulations that pertain to urban animals in the United States. Specifically, I have explored how laws attempt to sort animals into rigid classifications such as domestic and companion, agriculture and livestock, wild, and pest ani mals and how these different classes of animals are then subject to complex regulatory schemes that afford varying degrees of protection from human conduct.

Alongside the attempted rigidity of legal regimes on animals, this chapter has shown that fluidity and mobility are crucial aspects of the legal ordering of human animal relations, especially as these relations manifest in the humanly dense space of the city. The honeybee in particular has served to demonstrate how animals are subject to, and themselves affect, legal and administrative practices.

Levels of animal rigidity and mobility also vary with respect to the treatment of the same species under parallel laws. Indeed, states and

82 See Beesource Beekeeping: Laws Relative to Bees and Beekeeping, http://www. beesource.com/resources/elements-of-beekeeping/laws-related-to-bees-and beekeeping/ (last visited Oct. 11, 2011). Ironically, the solution in Brazil has been to retame the Africanized honeybee by culling the queens of aggressive hives and breeding more docile African queen bees. In the United States, scientists advise beekeepers to use the same method of culling aggressive hives and actively breeding docile hives. See E. H. Erickson, B. J. Erickson, H. H. Laidlaw, \& L. Moore, Preparing for the "Africanized" Honey Bee: A Program for Arizona, http://www.beesource.com/point-of-view/africanized-honey-bees/preparing-for-theafricanized-honey-bee-a-program-for-arizona/ (last visited Oct. 21, 2011). Since the bees are visually indistinguishable, beekeepers must judge each hive, European, African, or hybrid, by its behavior. 
municipalities use different categories to refer to identical species, resulting in that a particular species is defined differently under different laws. ${ }^{8}$ For example, a pig or a horse may be defined as a companion animal under anticruelty provisions and as livestock under provisions regulating agribusi ness. Legislatures may also reclassify animals within the same laws at different times. In Missouri, for example, ostriches were reclassified from exotic animals to livestock, ${ }^{84}$ and numerous examples exist of "listing" and "delisting" animals into and out of their designation as "wild" and "endan gered" by the U.S. Fish and Wildlife Service. ${ }^{85}$

In contrast to the legal mobility of potbellied pigs between categories of livestock and pet, the New York State conservation law requires the killing of any domestic dog that hunts a deer and of any wild coyote that kills a domestic animal. Such instances demonstrate the intolerance of law toward the mobility of dogs and coyotes between the legal categories of domestic and wild. Particular reclassifications have been established to manage such transgression: a domestic dog that kills a deer does not become a protected wild animal but instead a feral dog; a wild coyote that kills a pet becomes a nuisance coyote, categorically different from a wild animal with protections. As a result of law's heightened regulation of animal mobility in such cases, the feral dog and the nuisance coyote may both be killed. The execution powers are reserved to the sovereign, here in the form of government officials who are authorized to reorder the domestic wild boundary.

Alongside law's attempt to classify animals, a considerable effort also goes into keeping animals confined within their particular classificatory spaces. The prohibitions from keeping wild and farm animals as pets and those that prohibit treating pets as pests or pests as pets all point to the desire of law makers to keep animals under the tight controls and within the rigid confines of their static classifications so as to keep cities safe, sanitized, and free of animal nuisances.

At the same time, human and nonhuman animals also express their own, sometimes conflicting, trajectories that often transgress and challenge their fixity within the legal categories, forcing lawmakers and enforcers to adapt or

83 Animal L., at 7.

${ }^{8}$ Id. See also Levine v. Conner, 540 F.Supp.2d 1113, 1116 (N.D. Cal. 2008). There, the court analyzed the dictionary definition of the term "livestock" and observed that "the scope of domestic animals used or raised on a farm can potentially extend to guinea pigs, cats, dogs, fish, ants, and bees."

${ }_{5}$ See, e.g., U.S. Fish and Wildlife Endangered Species Bulletin at http://www.fws.gov/endangered/news/bulletin.html (last viewed June 16, 2013). 
develop new ways of regulating disorderly natures so as to redefine, reestablish, and reinforce order. My reading in this chapter thus illuminates how legal regimes accompany, dictate, and respond to human animal coexistence in the city and how such legalities both translate and reflect human animal practices and materialities in the city. 